Review

\title{
The Dichotomy of the Poly(ADP-Ribose) Polymerase-Like Thermozyme from Sulfolobus solfataricus
}

\author{
Maria Rosaria Faraone Mennella 1,2 (D) \\ 1 Department of Biology, University of Naples “Federico II", 80126 Naples, Italy; faraone@unina.it; \\ Tel.: +39-081-796 (ext. 136); Fax: +39-081-796223 \\ 2 National Institute of Biostructures and Biosystems (INBB), via delle Medaglie d'Oro, 00136 Rome, Italy \\ Received: 13 December 2017; Accepted: 30 January 2018; Published: 31 January 2018

\begin{abstract}
The first evidence of an ADP-ribosylating activity in Archaea was obtained in Sulfolobus solfataricus(strain MT-4) where a poly(ADP-ribose) polymerase (PARP)-like thermoprotein, defined with the acronymous PARPSso, was found. Similarly to the eukaryotic counterparts PARPSso cleaves beta-nicotinamide adenine dinucleotide to synthesize oligomers of ADP-ribose; cross-reacts with polyclonal anti-PARP-1 catalytic site antibodies; binds DNA. The main differences rely on the molecular mass $\left(46.5 \mathrm{kDa}\right.$ ) and the thermophily of PARPSso which works at $80{ }^{\circ} \mathrm{C}$. Despite the biochemical properties that allow correlating it to PARP enzymes, the N-terminal and partial amino acid sequences available suggest that PARPSso belongs to a different group of enzymes, the DING proteins, an item discussed in detail in this review.This finding makes PARPSso the first example of a DING protein in Archaea and extends the existence of DING proteins into all the biological kingdoms. PARPSsohas a cell peripheral localization, along with the edge of the cell membrane. The ADP-ribosylation reaction is reverted by a poly(ADP-ribose) glycohydrolase-like activity, able to use the eukaryotic poly(ADP-ribose) as a substrate too. Here we overview the research of (ADP-ribosyl)ation in Sulfolobus solfataricus in the past thirty years and discuss the features of PARPSso common with the canonical poly(ADP-ribose) polymerases, and the structure fitting with that of DING proteins.
\end{abstract}

Keywords: Archaea; Crenarcheota; DING proteins; PARG; PARP; PARPSso; poly(ADP-ribosyl)ation; Sulfolobus solfataricus

\section{Introduction}

Sulfolobus solfataricus, a thermophilic archaeon, belongs to the kingdom of Archaea that includes extremophiles very interesting from both evolutionary and biotechnological point of view [1]. It has been assigned to the archaeal subdivision termed the Crenarchaea [1]. For many years S. solfataricus (strain P2) has been the model organism for studying crenarchaeal biology [2,3], and itsgenome sequence has been exploited extensively [4]. The data reveal a high proportion of archaea-specific genes and reinforce the major differences between archaea, bacteria, and eukarya. Clear differences are also discernible between the Crenarchaea and Euryarchaea in their DNA replication and translation mechanisms in their cell cycle processes [4].

In 1980 Kessel andKlink reported that diphtheria toxin catalyzes the ADP-ribosylation ofelongation factors from some Archaea including Sulfolobus [5]. One well-establisheddifference between prokaryotes and eukaryotes is the specificity of diphtheria toxin reaction; the toxin modifies by adenosine diphosphate-ribose (ADPR) the eukaryotic elongation factor EF2 but not the homologous prokaryotic factor EF-G, highlighting that archaeal factors are eukaryotic EF2-like [6]. 
In light of the report of Kessel and Klink [5], Faraone-Mennella et al. investigated for thefirst time the presence of endogenous (ADP-ribosyl)ation in the hyperthermophilic archaeon S. solfataricus [7-9].

Sulfolobus solfataricus, specifically the strain MT-4, is isolated from acidic hot springs in Agnano (Napoli, Italy), where it lives optimally at $87^{\circ} \mathrm{C}$ and $\mathrm{pH}$ 3.5. S. solfataricus was selected as a model system to study the (ADP-ribosyl)ation reaction because it is aerobic and it is readily cultivated in liquid and solid media in both complex and defined medium $[10,11]$. The group of researchers who determined the complete genome of $S$. solfataricus found that $\mathrm{NAD}^{+}$is used rarely as an electron acceptor in some central metabolic redox reactions of this organism, but the levels of $\mathrm{NAD}^{+}$are enough high to account for both coenzyme and substrate roles of the pyridinic compound [4]. This finding was interesting for the present research since $\mathrm{NAD}^{+}$is a substrate in the (ADP-ribosyl)ation reaction.

The aim of this review is to retrace the steps of the research on (ADP-ribosyl)ation in Sulfolobus solfataricus MT-4 and discuss the biochemical and kinetic similarities of PARPSso with the eukaryotic enzymes, but also the structural difference (i.e., size and amino acid sequence) of the thermozyme from the canonical poly(ADP-ribose)polymerases, which allow assigning the Sulfolobus (ADP-ribosyl)ating enzyme to the group of DING proteins.

\section{The Poly(ADP-Ribose)Polymerase-Like Enzyme in S. solfataricus}

The Sulfolobus (ADP-ribosyl)ating enzyme is temperature-, time-, and NAD ${ }^{+}$-dependent and shows a high thermostability [12]. This is the first example of a poly(ADP-ribose)polymerase-like activity described in any archaeal species.

The first evidence of a poly(ADP-ribose)polymerase-like activity was obtained immunochemically in the archaeal homogenate by means of anti-poly(ADP-ribose) polymerase antibodies [13] and was confirmed by the ability of the thermozyme to elongate the ADP-ribose chain to synthesize short oligomers (up to $4-5$ units) [12]. This product behaves like the eukaryotic polymer when treated in vitro with degrading enzymes, namely, phosphodiesterase, giving rise to AMP and iso-ADPR, and phosphatase $[9,12]$. Moreover, the pentameric ADP-ribose chain is recognized as a substrate also by eukaryotic poly(ADP-ribose) glycohydrolase (PARG) and is degraded by a Sulfolobus PARG-like enzyme [14].

The PARP-like thermozyme (PARPSso) was purified to electrophoretic homogeneity [12]. The availability of the purified PARPSso allowed studying extensively its biochemical and kinetic properties.The thermozyme ( $\mathrm{MW}=46.5 \mathrm{kDa}$ ) works at an optimal temperature of $80^{\circ} \mathrm{C}$ and has a half-life of $204 \mathrm{~min}$ at $80^{\circ} \mathrm{C}$, in good agreement with the requirements of a thermozyme. It displays a $\mathrm{K}_{\mathrm{M}}$ towards $\mathrm{NAD}^{+}$of $154 \pm 50 \mu \mathrm{M}$ [12] and does not recognize NADH and NADP as substrates. Well known inhibitors of the mesophilic $116 \mathrm{kDa}$ enzyme like zinc ions, nicotinamide, 3-aminobenzamide exert a smaller effect on PARPSso, reducing the activity to 50\% [15]. Magnesium is a positive effector [16]. With respect to the charge, PARPSso ( $\mathrm{pI}=7.0-7.2$ ) behaves differently from the eukaryotic poly(ADP-ribose)polymerase, described as a basic protein $(\mathrm{pI}=9.5)$. The amino acid composition of the thermozyme shows a more hydrophobic protein than the eukaryotic enzymes are [16]. It was hypothesized that a more apolar environment is one of the bases of the intrinsic high thermostability of the archaeal enzyme. With respect to size and content of some amino acids, PARP2 $(62 \mathrm{kDa})$ is in a middle position between PARP $1(116 \mathrm{kDa})$ and PARPSso (46.5 kDa) [16]. PARPSso structure is indeed influenced by temperature, with a conformational transition below $60{ }^{\circ} \mathrm{C}$ and a full stabilization of conformation above this value, indicating that the correct folding occurs at high temperature [17].

As for nuclear eukaryotic PARPs, the thermozyme binds DNA with high affinity $\left(\mathrm{K}=2 \times 10^{9} \mathrm{M}^{-1}\right)$ and non-specifically, independently from the base composition and length of the nucleic acid, with a slight preference for the circular structure [18]. Enzyme activity is DNA-dependent. The presence of circular DNA is able to increase PARPSso activity by $80 \%$ [18].

PARPSsocatalyzes both automodification and heteromodification reactions.

S. solfataricus homogenate, incubated with radiolabeledNAD ${ }^{+}$, and radioactive protein extracts showed ADPR acceptor proteins in a wide range of molecular masses, mainly associated with 
standardsranging from $7 \mathrm{kDa}$ to $50 \mathrm{kDa}$ [9]. Most of these acceptors of ADP-ribose are still unidentified, but both the $50 \mathrm{kDa}$ and $7 \mathrm{kDa}$ proteins correspond to PARPSso and to DNA-condensing proteins (the so-called Sso7 (a, b, c, d, e) family), respectively [12,19]. Automodification of PARPSso was demonstrated both by activity gel and by using the pure thermozyme as a unique ADPR acceptor in the enzymatic assay [12].

Heteromodification of Sso7, namely, Sso7d, was demonstrated by in vitro reconstitution experiments, where both purified PARPSso and purified heteroacceptorwere incubated in the presence of radiolabelled $\mathrm{NAD}^{+}$. Sso7 was oligo(ADP-ribosyl)ated by the thermozyme with an ADP-ribose chain of 4-5 residues [19]. Under the used experimental conditions labeling of Sso7 was preferential. Sso7 protein, as the other members of the family, is a small $(7 \mathrm{kDa})$, basic, and nonhistone-like protein, highly expressed in this microorganism ([20] and references therein). At the N-terminus, it is characterized by a structural motif (X-K-X-K-X-K) resembling that present in eukaryotic high mobility group (HMG) proteins [21]. The $7 \mathrm{kDa}$ proteins can form compacted nucleoprotein particles with both double- and single-stranded DNA [20,21], and one of them, Sso7d, is able to renature in vitrohomologous single strands of the nucleic acid at a temperature at which the spontaneous hybrid is not stable [22].

Thanks to the use of immunofluorescent anti-human PARP1 catalytic site antibodies, cell localization ofPARPSso was determined (see Figure 1) [23]. PARPSso localizes along the plasma membrane hedge. Less intense, but clearly occurring, is the merge of immunosignal with nucleoid, as confirmed by anti-poly(ADP-ribose) polymerase immunoblottings showing the presence of Sulfolobus thermozyme in membrane fractions, as well as in association with nucleoid DNA [23].

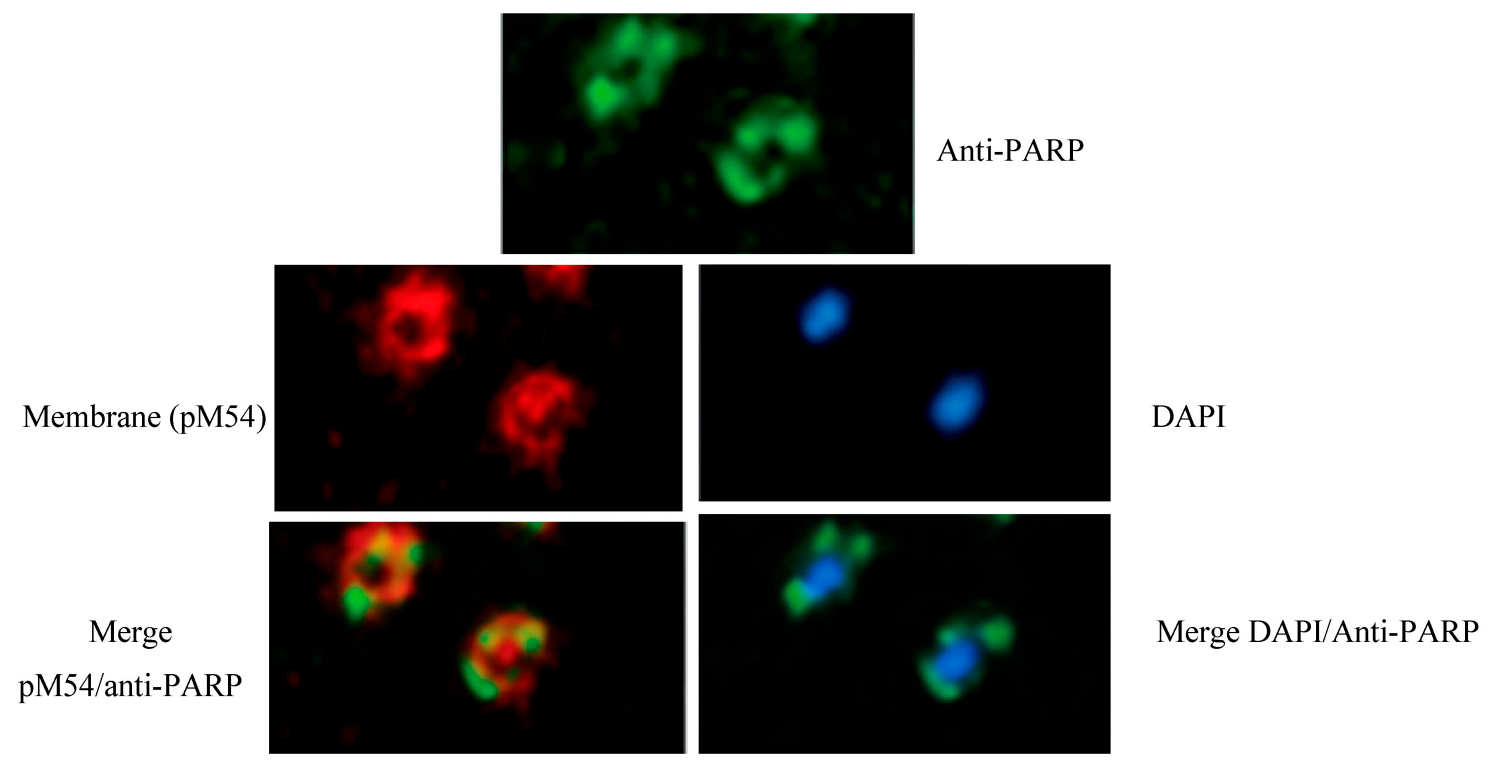

Figure 1. Cell immunolocalization of PARPSso. Fluorescent anti-PARP1 antibodies (green) showed the PARPSsoimmunosignal localized close to the membrane, at the periphery of the cell. PARPSso signal is also overlapping or strictly close to the nucleoid. Blue, nucleoid staining with DAPI; red, membrane staining with pM54.

\section{PARPSso and the World of PARPs}

To better understand the steps that have allowed developing the research on (ADP-ribosyl)ation in Sulfolobus and to interpret the results that were being achieved, it is important to retrace the history of both PARPSso and PARPs, which have had a parallel path.

In 1966, Mandel's group discovered an $\mathrm{NAD}^{+}$consuming reaction in which poly(ADP-ribose) (PAR) chains were synthesized [24]. A few years later, at the time this research started, the literature on poly(ADP-ribosyl)ation became wider and wider. Researchers' attention focused on the enzyme 
synthesizing PAR, PAR synthetase (PARS), later indicated as poly(ADP-ribose) polymerase, PARP [25,26]. In the nineties, only the existence ofa unique poly(ADP-ribose) polymerase (116 kDa) was accepted. It was unconceivable that the occurrence of a poly(ADP-ribosyl)ating enzyme was as as small-sized as less than $50 \mathrm{kDa}$, and the Sulfolobus PARP-like enzyme was mostly considered as a mono-ADP-ribosylating enzyme, despite the evidence thatits catalysis included the elongation step. From 1999, the year the PARP2 gene was discovered [27], many other PARPs (in total 18) were found which were grouped in the PARP superfamily [28]. The family is characterized by a highly-conserved catalytic site, including a consensus sequence called the PARP signature. The most recent research has shown that some members within the PARP superfamily have altered catalytic sites, and have mono(ADP-ribose) transferase (mART) activity or are enzymatically inactive, suggestingthat the PARP signature has a broader range of functions than initially predicted [29]. A phylogenetic analysis led identifying in silico236 PARP proteins from 77 eukaryotic species and suggested that the ancestral eukaryote had at least two PARP enzymes [29,30]. Despite the strict membership of PARPs to the eukaryotic kingdom and the hypothesized origin from two ancestral eukaryotic PARP enzymes, the presence of a PARP-like gene was demonstrated in viruses, including a baculovirus too [31,32]. The viral gene codes for a polypeptide with a conserved catalytic domain, but lacking the PARP auto modification domain [32]. PrpA is another example of a putative PARP in a fungal system (Aspergillus nidulans) that belongs to a group of PARP homologs including representatives from filamentous fungi and protists [33]. The genetic analysis of PrpA demonstrated that it is an essential gene whose role in the DNA damage response is sensitive to gene dosage [33].

A major point in the research on PARPs is the common structural feature, i.e., the conserved catalytic domain, of the family members and their homologues, mostly demonstrated on the basis of gene sequences, albeit its variability led to the absence of intrinsic PARP enzymatic activity. As for PARP homologs [27], this observation suggests that a broader range of functions than initially predicted on the basis of structural evidence might be [29]. Thus, a question arises: is it correct to define all of them as poly(ADP-ribose) polymerases, i.e., enzymes synthesizing poly(ADP-ribose)?

This consideration allows to ask a similar question about the situation observed for PARPSso. Since the PARP-like activity of PARPSso has been demonstrated by biochemical and kinetic results obtained with the purified enzyme, and not derived merely from the comparison of gene sequences, is it conceivable considering the Sulfolobus PARP-like enzyme an even more primordial precursor of the two ancestral eukaryotic PARPs discussed above? This hypothesis cannot be excluded by knowing that after divergence from Bacteria, Archaea and Eukarya had a common evolutionary path before separating into the two kingdoms.

Standing that the thermozyme has common biochemical and kinetic features with regular PARPs and is from Crenarchaea, which are very close to Eukaryotes, the structural features of PARPSso revealed an opposite situation: this enzyme shares its structure with DING proteins.

\section{PARPSso Belongs to the DING Protein Family}

After the whole genome sequence of Sulfolobus solfataricus P2 was published, it was clear that no canonical PARP gene was present therein [4]. Moreover, despite the biochemical properties allowed to correlate PARPSso to PARP enzymes, a first BLAST research of purified PARPSso towards classic PARPs was not fruitful: the structural analysis indicated that the sulfolobal enzyme had a different structure, resembling a new group of proteins, the DING proteins, Figure 2 [34-36].

Then the BLAST search was repeated by using the consensus sequences of specific PARP domains (WGR, macrodomain, $\mathrm{NAD}^{+}$and PAR binding, etc.). Not standing the amino acid sequence was different from that of PARPs, the amino terminal region contained motifs described as DNA and nucleotide binding (the initial cluster of glycins in the signature; the walker A motif, at residues 31-40; the WGR-like domain, WGK, residues 83-85) [37]. 

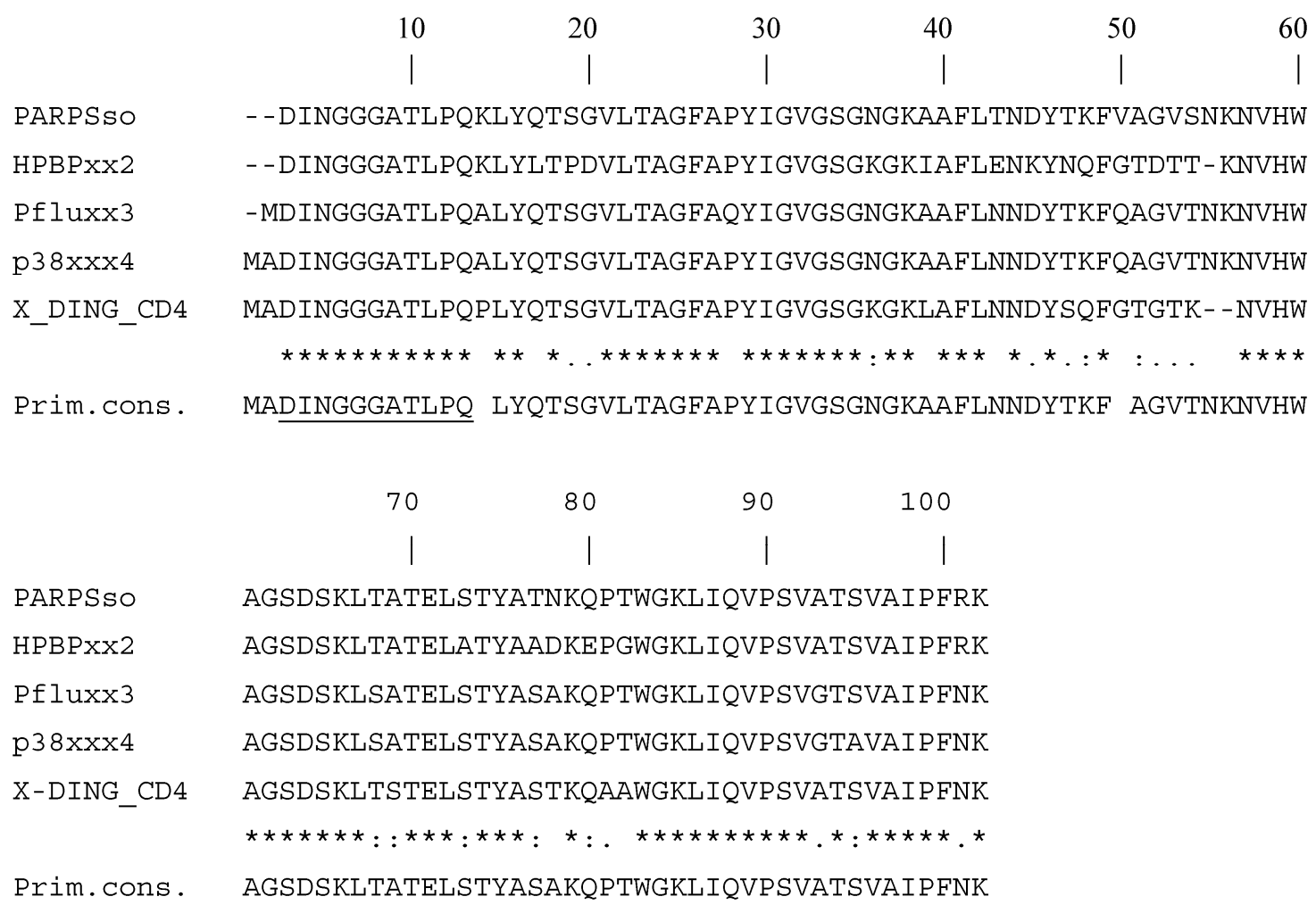

Figure 2. Alignment of the N-terminal region (102 amino acids) of some DING proteins. PARPSso, PARP-like enzyme, S. solfataricus (accession no. B3EWG9); HPBP, human phosphate binding apolipoprotein (accession no. 2V3Q_A); Pflu, Pseudomonas fluorescence SBW25 phosphatase (accession no. 4F1V_A); p38, human phosphate ion trans membrane transporter, (accession no. D7RXV9); X-DING_CD4, from HIV-1 resistant CD4(+) T cells, anti-viral activity (accession no. ADT62916); prim.cons., consensus sequence. ${ }^{*}$ ) unvariant amino acids; (:) conservativeand (.) non conservative changes. The signature sequence is underlined. Alignments were conducted with the CLUSTAL_W program, as described in [35].

The following BLAST search, with the partial amino acid sequence obtained from the purified PARPSso and available at UniProt site (Accession $\mathrm{N}^{\circ}$ B3EWG9), gave, as expected, a list of DING proteins from different organisms, aligning with the Sulfolobus enzyme. In particular, at the N-terminus there is a typical amino acid sequence which is considered the "signature" of these proteins, Figure 2 [36].

The sequence alignment of PARPSso with DING proteins confirms that it belongs to this family. This finding is relevant since it makes PARPSso the first example of a DING protein from Archaea and extends the existence of DING proteins into all the biological kingdoms [34].

All members of the DING family have a molecular mass of approximately $40 \mathrm{kDa}$ and a conserved N-terminal sequence (DINGGG) $([35,36]$ and references therein). They belong to the superfamily of bacterial phosphate-binding proteins [35]. The phosphate-binding site is strongly conserved and comprises eight conserved or conservatively-substituted residues, responsible to hydrogen-bind the phosphate ion with high affinity [35].

The peculiarity of these proteins is that they have beenserendipitously discovered as members of the DING group [35,36]. DING proteins have been mostly identified thanks to their biological functions and their number is expected to increase due to the possibility that some of them, perhaps already studied for their functions, are not structurally identified as DING proteins yet [35]. The high similarity of amino acid sequences and some highly conserved domains (phosphate binding sites) from prokaryotes to eukaryotes are surprising $[35,36]$. Surprising is also the diversity of activities displayed 
by DING proteins from different sources;among others apolipoprotein, protease, alkaline phosphatase, phosphodiesterase, nucleotidase, and secretion proteins have been identified and reviewed in [35,36].

The Sulfolobus (ADP-ribosyl)ating activity can be added to this list. It represents a further new activity, despite it has been very recently demonstrated that the enzyme can also behave as a phosphatase thanks to the highly-conserved P-binding site [38]. This finding is in line with the hypothesis that due to the fact that most DING proteins were discovered independently, before knowing they form a group, multiple functions have been discovered and, perhaps, each member of the family might exhibit more than one function [36,38]. Whether there is a common physiological function unifying DING proteins still needs to be determined. They are often associated with infections or with dysregulation of cell proliferation. DING proteins are involved in many diseases, including rheumatoid arthritis, lithiasis, atherosclerosis, some tumors, tumor-associated cachexia, and bacterial and viral infections $[35,36]$. In this context the clinical usefulness of purified PARPSso as an antigen to detect the presence of abnormal anti-PARP antibodies in the sera of patients with systemic lupus erythematosus (SLE) at different clinical stages was studied [38]. PARPSso seemed to be suitable for detecting anti-PARP antibodies and could play a role as a serological marker of disease activity in patients with SLE [39].

It is worth noting that independent research groups reported that DING protein homologues isolated from bacterial, plant and human cells demonstrate the anti-HIV-1 activity [40]. Bacterial PfluDING, plant p38SJ (pDING), human phosphate binding protein (HPBP), and human extracellular DING from CD4 T cells (X-DING-CD4) were able to block transcription of HIV-1 and replication of virus in cell based assays. Transcription of HIV-1 depends on NF-kB, involved in the immediate signaling mechanisms of the innate immunity responses against infecting pathogens, including HIV-1. Therefore, the anti-NF-kB activity of DING proteins is of particular interest and might indicate that diverse organisms utilize a DING-mediated broad-range protective innate immunity response to pathogen invasion, and that this mechanism is effective also against HIV-1 [40].

Despite recently many novel members have been identified, confirming that DING proteins are ubiquitous, their genes are mostly absent from databases, allowing to hypothesize that these proteins could be encoded by eukaryotic genes sharing special features that prevent their cloning $[35,36]$. The few genomic sequences that are now available are starting to indicate why DING protein genes and mRNAs are well conserved and difficult to clone. Compared to the wide numbers of DING members the knowledge of gene or mRNA sequences is scarce. Despite the genomes of most species, including Sulfolobus solfataricus P2, have been sequenced few gene information is available, limiting investigation in this field. Genes of DING proteins have been identified mainly in various Pseudomonas strains, and partial nucleotide sequences in some eukaryotes [36].

\section{Conclusions}

Although biochemically similar to PARP 1 , the partial amino acid sequence of PARPSso overlaps those of DING proteins $[34,36,37]$. This group of proteins, widely occurring in animals, plants, and eubacteria, shows a characteristic and highly-conserved N-terminus, DINGGGATL [35]. These structural findings (PARPSso is a DING protein) seem to be in contrast with the biochemical results (PARPSso is a PARP-like enzyme). Since its discovery in S. solfataricus, PARPSso has been subjected to a serious criticism, as the sulfolobal genome did include gene sequence corresponding neither to classic PARPs, nor to DING proteins [4]. Gene absence from the Sulfolobus genome is in accordance with the lack of homologous eukaryotic DING genes [35,36]. Nevertheless, biochemical, kinetic, and immunologicaldata, together with the characterization of the reaction products, allowed PARPSso to be defined as a PARP-like enzyme, although with specific features linked to its thermophilic nature. The fact that PARPSso is thermostable argues that it originates from thermophilic S. solfataricus and is not a contamination from Pseudomonas, as has been argued in the case of the eukaryotic proteins ([35,36] and references therein). The Sulfolobus protein has DNA-binding ability and exhibits a NAD ${ }^{+}$-dependent (ADP-ribosyl)ating activity that modifies specifically another sulfolobal DNA-binding protein, Sso7, with ADP-ribose oligomers $[25,26]$. This finding lets us hypothesize 
its possible role at least in regulating by (ADP-ribosyl)ation the DNA condensation-decondensation process driven by the $\mathrm{Sso7}$ protein. The addition of this new function to the number already described, allows to consider the world of DING proteins very complex, and that they might represent more than merely components of a membrane phosphate transport system as frequently suggested [35-38].

Far from drawing definite conclusions, we can hypothesize that DINGs and PARPs originated as a single protein with different structural modules that underwent different evolutionary fates to produce, in higher organisms, two structurally- and functionally-divergent proteins.

Many questions (the full amino acid sequence, the enzyme role(s), the mystery of the hidden gene), remain to be clarified and their investigation is the aim of the research in the nearfuture.

Acknowledgments: I wish to thank all of the co-workers listed in the References who engaged in the research on the poly(ADP-ribosyl)ation system in Sulfolobus from the far beginning up today, and those who will help to achieve new results in the future. A special thanks to Benedetta Farina and Anna De Maio. My thoughts to the memory of the pioneer of this research, Enzo Leone. We are grateful to Servizio Fermentazioni of CNR (Pozzuoli), directed first by Agata Gambacorta and now by Barbara Nicolaus, for its precious and valuable contribution to provide Sulfolobus solfataricus MT-4 cells.

Conflicts of Interest: The author declares no conflict of interest.

\section{References}

1. Woese, C.R.; Kandler, O.; Wheelis, M.L. Towards a natural system of organisms: Proposal for the domains Archaea, Bacteria and Eucarya. Proc. Natl. Acad. Sci. USA 1990, 87, 4576-4579. [CrossRef] [PubMed]

2. Pfeiffer, P.; Thode, S.; Hancke, J.; Vielmetter, W. Mechanisms of overlap formation in non homologous DNA end joining. Mol. Cell. Biol. 1994, 14, 888-895. [CrossRef] [PubMed]

3. De Rosa, M.; Gambacorta, A.; Bu'lock, J.D. Extremely thermophilic acidophilic bacteria convergent with Sulfolobus acidocaldarius. J. Gen. Microbiol. 1975, 86, 156-164. [CrossRef] [PubMed]

4. Singh, Q.; Confalonieri, R.K.; Zivanovic, Y.; Allard, G.; Awayez, M.J.; Chan-Weiher, C.C.; Clausen, I.G.; Curtis, B.A.; De Moors, A.; Erauso, G.; et al. The complete genome of the Crenarchaeon Sulfolobus solfataricus P2. Proc. Natl. Acad. Sci. USA 2001, 98, 7835-7840.

5. Kessel, M.; Klink, F. Archaebacterial elongation factor is ADP-ribosylated by diphtheria toxin. Nature 1980, 287, 250-251. [CrossRef] [PubMed]

6. Honjo, T.; Nishizuka, Y.; Hayaishi, O.; Kato, I. Diphtheria Toxin-dependent Adenosine Diphosphate Ribosylation of Aminoacyl Transferase II and Inhibition of Protein Synthesis. J. Biol. Chem. 1968, 243, 3553-3555. [PubMed]

7. Quesada, P.; Faraone-Mennella, M.R.; De Rosa, M.; Gambacorta, A.; Nicolaus, B.; Farina, B. ADP-Ribosylating Activity in Sulfolobus solfataricus. In ADP-Ribose Transfer Reactions; Jacobson, M.K., Jacobson, E., Eds.; Springer: New York, NY, USA, 1989; pp. 101-104.

8. Faraone-Mennella, M.R.; De Lucia, F.; Quesada, P.; De Rosa, M.; Gambacorta, A.; Nicolaus, B.; Farina, B. Heterogeneity of ADP-ribosylation Reaction in Sulfolobus solfataricus. In ADP-Ribosylation Reactions; Poirier, G.G., Moreau, P., Eds.; Springer: New York, NY, USA, 1992; pp. 369-372.

9. Faraone-Mennella, M.R.; De Lucia, F.; De Maio, A.; Gambacorta, A.; Quesada, P.; De Rosa, M.; Nicolaus, B.; Farina, B. ADP-ribosylation reactions in Sulfolobus solfataricus, a thermoacidophilic archaeon. Biochim. Biophys. Acta 1995, 1246, 151-159. [CrossRef]

10. Gambacorta, A.; Gliozzi, A.; De Rosa, M. Archaeal lipids and their biotechnological applications. World J. Microbiol. Biotechnol. 1995, 11, 115-131. [CrossRef] [PubMed]

11. Nicolaus, B.; Trincone, A.; Lama, L.; Romano, I.; Marsiglia, F.; Gambacorta, A. Adaptation of Sulfolobus solfataricus on minimal media. Biotechnol. Lett. 1991, 13, 667-670. [CrossRef]

12. Faraone-Mennella, M.R.; Gambacorta, A.; Nicolaus, B.; Farina, B. Purification and biochemical characterization of a poly(ADP-ribose) polymerase-like enzyme from the thermophilic archaeon Sulfolobus solfataricus. Biochem. J. 1998, 335, 441-447. [CrossRef] [PubMed]

13. Faraone-Mennella, M.R.; Gambacorta, A.; Nicolaus, B.; Farina, B. Immunochemical detection of ADP-ribosylating enzymes in the archaeon Sulfolobus solfataricus. FEBS Lett. 1996, 378, 199-201. [CrossRef] 
14. De Maio, A.; Porzio, E.; D’Angelo, R.; Rotondo, S.; Bianchi, A.R.; Confalone, E.; Raucci, R.; Natale, E.; Faraone-Mennella, M.R. A Glycosyltransferase from Sulfolobus solfataricus MT-4 Exhibits Poly(ADP-ribose) Glycohydrolase Activity. Curr. Proteom. 2015, 12, 253-263. [CrossRef]

15. Faraone-Mennella, M.R.; De Lucia, F.; De Maio, A.; Gambacorta, A.; Nicolaus, B.; Farina, B. ADPribosylation reaction by free ADPribose in Sulfolobus solfataricus, a thermophilic archaeon. J. Cell. Biochem. 1997, 66, 37-42. [CrossRef]

16. Faraone-Mennella, M.R.; Castellano, S.; De Luca, P.; Discenza, A.; Gambacorta, A.; Nicolaus, B.; Farina, B. Comparison of the ADP-ribosylatingthermozyme from Sulfolobus solfataricus and the mesophilic poly(ADP-ribose) polymerases. FEMS Microbiol. Lett. 2000, 192, 9-14. [CrossRef] [PubMed]

17. Faraone-Mennella, M.R.; Discenza, A.; Gambacorta, A.; Nicolaus, B.; Farina, B. Purification of the ADP-ribosylating enzyme from $S$. solfataricus by SDS-polyacrylamide gel electrophoresis and electroelution. Prep. Biochem. Biotechnol. 2000, 30, 61-67. [CrossRef] [PubMed]

18. Faraone-Mennella, M.R.; De Luca, P.; Giordano, A.; Gambacorta, A.; Nicolaus, B.; Farina, B. High stability binding of poly(ADPribose) polymerase-like thermozyme from $S$. solfataricus with circular DNA. J. Cell. Biochem. 2002, 85, 158-166. [CrossRef] [PubMed]

19. Faraone-Mennella, M.R.; Farina, B. In the thermophilic archaeon Sulfolobus solfataricus a DNA-binding protein is in vitro (ADP-ribosyl)ated. Biochem. Biophys. Res. Commun. 1995, 208, 55-62.

20. Reeve, J.N. Archaeal chromatin and transcription. Mol. Microbiol. 2003, 48, 587-598. [CrossRef] [PubMed]

21. Baumann, H.; Knapp, S.; Lundback, T.; Ladenstein, R.; Hard, T. Solution structure and DNA-binding properties of a thermostable protein from the archaeon Sulfolobus solfataricus. Nat. Struct. Biol. 1994, 1, 808-819. [CrossRef] [PubMed]

22. Guagliardi, A.; Cerchia, L.; Rossi, M. The Sso7d protein of Sulfolobus solfataricus: In Vitro relationship among different activities. Archaea 2002, 1, 87-93. [CrossRef] [PubMed]

23. Porzio, E.; Bianchi, A.R.; Baccigalupi, L.; Isticato, R.; Faraone Mennella, M.R. The DINGGG thermoprotein is membrane bound in the Crenarchaeon Sulfolobus solfataricus. Chem. Biol. Technol. Agric. 2016, 3. [CrossRef]

24. Doly, J.; Mandel, P. Demonstration of the biosynthesis in vivo of a compound polymer, polyadenosine diphosphoribose in the nucleus of the liver of chickens. C. R. Acad. Sci. Hebd. Seances Acad. Sci. D 1967, 264, 2687-2690. [PubMed]

25. Zahradka, P.; Ebisuzaki, K. Poly(ADP-ribose) polymerase is a zinc metalloenzyme. Eur. J. Biochem. 1984, 142, 503-509. [CrossRef] [PubMed]

26. Mazen, A.; Menissier-de Murcia, J.; Molinete, M.; Simonin, F.; Gradwohl, G.; Poirier, G.; de Murcia, G. Poly(ADP-ribose)polymerase: A novel finger protein. Nucleic Acids Res. 1989, 17, 4689-4698. [CrossRef] [PubMed]

27. Amé, J.C.; Rolli, V.; Schreiber, V.; Niedergang, C.; Apiou, F.; Decker, P.; Muller, S.; Höger, T.; Ménissier-de Murcia, J.; de Murcia, G. PARP-2, A novel mammalian DNA damage-dependent poly(ADP-ribose) polymerase. J. Biol. Chem. 1999, 274, 17860-17868. [CrossRef] [PubMed]

28. Hottiger, M.O.; Hassa, P.O.; Luscher, B.; Schuler, H.; Koch-Nolte, F. Toward a unified nomenclature for mammalian ADP-ribosyltransferases. Trends Biochem. Sci. 2010, 35, 208-219. [CrossRef] [PubMed]

29. Citarelli, M.; Teotia, S.; Lamb, R.S. Evolutionary history of the poly(ADP-ribose) polymerase gene family in eukaryotes. BMC Evol. Biol. 2010, 10, 308. [CrossRef] [PubMed]

30. Helge, O.; Reche, P.A.; Bazan, F.; Dittmar, K.; Haag, F.; Koch-Nolte, F. In Silico characterization of the family of PARP-like poly(ADP-ribosyl)transferases (pARTs). BMC Genomics 2005, 6, 139. [CrossRef]

31. Perina, D.; Mikoč, A.; Ahel, J.; Ćetković, H.; Žaja, R.; Ahel, I. Distribution of protein poly(ADP-ribosyl)ation systems across all domains of life. DNA Repair (Amst) 2014, 23, 4-16. [CrossRef] [PubMed]

32. Velasco de Castro Oliveira, J.; de Melo, F.L.; Malta Romano, C.; Iamarino, A.; Sampaio Rizzi, T.; Peres Yeda, F.; Hársi, C.M.; Caldas Wolff, J.L.; Marinho de Andrade Zanotto, P. Structural and phylogenetic relationship of ORF 31 from the Anticarsiagemmatalis MNPV to poly (ADP-ribose) polymerases (PARP). Virus Genes 2008, 37, 177-184. [CrossRef] [PubMed]

33. Semighini, C.P.; Savoldi, M.; Goldman, G.H.; Harris, S.D. Functional characterization of the putative Aspergillus nidulans poly(ADP-ribose) polymerase homolog PrpA. Genetics 2006, 173, 87-98. [CrossRef] [PubMed] 
34. Di Maro, A.; De Maio, A.; Castellano, S.; Parente, A.; Farina, B.; Faraone-Mennella, M.R. The ADPribosylatingthermozyme from Sulfolobus solfataricus is a DING protein. Biol. Chem. 2009, 390, 27-30. [CrossRef] [PubMed]

35. Berna, A.; Scott, K.; Chabrière, E.; Bernier, F. The DING family of proteins: Ubiquitous in eukaryotes, but where are the genes? Bioessays 2009, 31, 570-580. [CrossRef] [PubMed]

36. Bernier, F. DING proteins: Numerous functions, elusive genes, a potential for health. Cell. Mol. Life Sci. 2013, 70, 3045-3056. [CrossRef] [PubMed]

37. Porzio, E. The Relationship of the ADP-Ribosylating Enzyme from S. solfataricus with DING Proteins and Its Intracellular Localization. Ph.D. Thesis, University of Naples “Federico II”, Naples, Italy, 2010.

38. Porzio, E.; De Maio, A.; Ricciardi, T.; Mistretta, C.; Manco, G.; Faraone-Mennella, M.R. Comparison of the archaeal DING protein from the archaeon Sulfolobus solfataricus with Human Phosphate Binding Protein and Pseudomonas fluorescence DING counterparts. Extremophiles 2018. [CrossRef] [PubMed]

39. Faraone-Mennella, M.R.; Scarpa, R.; Petrella, A.; Manguso, F.; Peluso, R.; Farina, B. Detecting clinical activity in systemic lupus erythematosus with an archaeal poly(ADP-ribose) polymerase-like thermozyme: A pivotal study. Biomarkers 2009, 14, 381-387. [CrossRef] [PubMed]

40. Sachdeva, R.; Darbinian, N.; Khalili, K.; Amini, S.; Gonzalez, D.; Djeghader, A.; Chabriére, E.; Suh, A.; Scott, K.; Simm, M. DING Proteins from Phylogenetically Different Species Share High Degrees of Sequence and Structure Homology and Block Transcription of HIV-1 LTR Promoter. PLoS ONE 2013, 8. [CrossRef] [PubMed]

(C) 2018 by the author. Licensee MDPI, Basel, Switzerland. This article is an open access article distributed under the terms and conditions of the Creative Commons Attribution (CC BY) license (http:/ / creativecommons.org/licenses/by/4.0/). 